\title{
Carboplatin interaction with calf-thymus DNA: A FTIR spectroscopic approach
}

\author{
Deepak K. Jangir ${ }^{\mathrm{a}}$, Gunjan Tyagi ${ }^{\mathrm{a}}$, Ranjana Mehrotra ${ }^{\mathrm{a}, *}$, Suman Kundu ${ }^{\mathrm{b}}$ \\ ${ }^{a}$ Optical Radiation Standards, National Physical Laboratory, Dr. K.S. Krishnan Road, New Delhi 110 012, India \\ ${ }^{\mathrm{b}}$ Department of Biochemistry, University of Delhi (South Campus), Delhi 110 021, India
}

\section{A R T I C L E I N F O}

\section{Article history:}

Received 2 September 2009

Received in revised form 26 January 2010

Accepted 26 January 2010

Available online 1 February 2010

Keywords:

DNA

Carboplatin

FTIR spectroscopy

CD spectroscopy

Intrastrand cross-links

Conformation

\author{
A B S T R A C T
}

Carboplatin is a chemotherapeutic drug, used for the treatment of different types of cancers, particularly solid tumors. Carboplatin, like other platinum containing drugs, exerts its cytotoxic effect through DNA binding via cross-linking. It forms interstrand and intrastrand cross-linking with DNA. Intrastrand crosslinking is dominant and believed to be conferring antitumoral efficacy of the drug. This cross-linking results in alteration of DNA winding and bending, which hampers DNA replication and transcription and finally leads to cell death. In the present work, we studied the interaction of carboplatin with calfthymus DNA in buffer solution under physiological conditions. Different concentrations of carboplatin were incubated with a constant DNA concentration to form carboplatin-DNA complexes. These complexes were studied with Fourier Transform Infrared (FTIR) spectroscopy and circular dichroism (CD) spectroscopy to understand the binding modes of carboplatin with DNA and its effect on DNA conformation. The results showed that carboplatin binds to DNA through direct interaction of platin-DNA bases (guanine, thymine, adenine and cytosine), with a small perturbation of phosphate group of DNA backbone, while DNA remains in the B-conformation. DNA aggregation was also observed at higher drug concentrations.

\section{Introduction}

Carboplatin is a cisplatin derivative, having bidentate cyclobutane dicarboxylate (CBDCA) moiety as its leaving group in contrast to the more readily leaving chloro groups of cisplatin (Fig. 1). Carboplatin is used to treat many types of cancer like ovarian carcinoma, lung, head and neck cancers. It is increasingly used for cancer treatment because of its advantage over parental drug cisplatin in exerting lower side effects [1].

Although there are many theories to explain cytotoxicity mediated by platinum containing anticancer drugs, but covalent binding to DNA is believed to be responsible for their cytotoxicity [2-4]. They form interstrand and intrastrand cross-links with nitrogenous bases of deoxyribonucleic acid. Intrastrand cross-linking is believed to be more important for platin mediated cytotoxicity [5]. Two adjacent guanines $\mathrm{d}(\mathrm{GpG})$ and, adjacent adenine and guanine $\mathrm{d}(\mathrm{ApG})$ residues are involved in intrastrand cross-links. This crosslinking results in unwinding and bending of the DNA duplex [6-8]. These changes in DNA structures hamper DNA replication and transcription. Although there is a mismatch excision repair system in the cell, but DNA adducts formed by platinum drugs are poorly repaired by this system $[3,9]$. This is due to shielding effect of DNA binding proteins [9-11]. This error in DNA repair mechanism activates cell apoptic signals, leading to cell death $[12,13]$.

Fourier Transform Infrared (FTIR) spectroscopy is a well-established technology to study interactions of nucleic acids (DNA and RNA) and proteins with anticancer drugs and other cytotoxic agents [14-19] in solutions. FTIR has the advantage of generating structural information of the entire molecule in a single spectrum as a "snapshot" of all conformations present in the sample. The technique is ideal for systematic studies of nucleic acids (e.g. sequence variations, covalent modifications), since it is fast, nondestructive, and requires only small amounts of sample. Along with FTIR, circular dichroism (CD) spectroscopy can be used to study conformational changes of biomolecules [20,21].

In the present work, carboplatin interaction was investigated with calf-thymus DNA under physiological conditions. Different carboplatin/DNA ratios, $r=1 / 100,1 / 50,1 / 20,1 / 10$ and $r=1 / 40,1 /$ $20,1 / 10,1 / 5$ were analyzed to study the binding properties of carboplatin using FTIR and CD spectroscopic techniques, respectively.

\section{Materials and methods}

\subsection{Materials}

Carboplatin and highly polymerized Type I calf-thymus DNA sodium salt (sodium content 6\%) were procured from Sigma-Aldrich chemicals (USA) and used without further purification. Purity of 


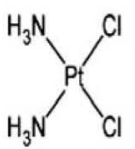

(a)

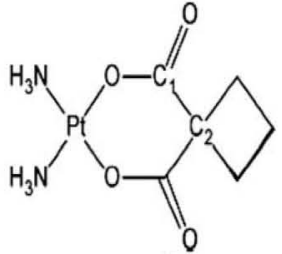

(b)
Fig. 1. Chemical structure of (a) cisplatin, (b) carboplatin.

the DNA was checked spectrophotometrically. The absorbance ratio $A_{260} / A_{280}$ was found 1.86 for the DNA, showing that the sample was sufficiently free of proteins. Other chemicals and reagents were of analytical grade and used as supplied. Ultra pure water was used for preparation of buffer solution and carboplatin solutions of different concentrations.

\subsection{Preparation of stock solutions}

Stock solution of DNA was prepared by dissolving $10 \mathrm{mg}$ of calf-thymus DNA per milliliter of $10 \mathrm{mM}$ Tris-HCl buffer $(\mathrm{pH}$ 7.4). The stock solution was kept at $8{ }^{\circ} \mathrm{C}$ for $24 \mathrm{~h}$ and stirred occasionally for complete homogenization. Final concentration of the stock DNA solution was measured spectrophotometrically using excitation coefficient of $6600 \mathrm{~cm}^{-1}$ [22]. The UV absorbance of 250 times diluted DNA solution was found 0.740 at $260 \mathrm{~nm}$ with a pathlength of $1 \mathrm{~cm}$. The final concentration of DNA stock solution was $28 \mathrm{mM}$ (molarity of phosphate group). The carboplatin solution was prepared in ultra pure water and incubated for $96 \mathrm{~h}$ for complete hydrolysis. A series of solutions with varying concentrations of carboplatin were prepared. Carboplatin solutions of different concentration so prepared were added drop by drop to DNA solutions. The carboplatin/DNA ratios $(r)$ were kept $1 / 100,1 / 50,1 / 20$ and $1 / 10$. The final concentration of the DNA was $14 \mathrm{mM}$ in all the solutions used for infrared measurements. For circular dichroism spectroscopy, the carboplatin/DNA ratios were kept $1 / 40,1 / 20,1 / 10$ and $1 / 5$ with a final DNA concentration of $2.5 \mathrm{mM}$.

\subsection{FTIR spectra}

FTIR spectra were obtained with a Varian 660-IR spectrophotometer, equipped with DTGS (deuterated triglycine sulphate) detector and $\mathrm{KBr}$ beam splitter assembly. Spectra were recorded after $2 \mathrm{~h}$ incubation of carboplatin with DNA. Liquid samples were tightly packed in a liquid cell made up of two ZnSe windows for infrared measurements. One hundred and twenty-eight scans were accumulated for each sample in the $4000-650 \mathrm{~cm}^{-1}$ spectral range with a resolution of $4 \mathrm{~cm}^{-1}$. Background spectra were collected before each measurement. All the measurements were carried out at room temperature and controlled ambient humidity of $45 \% \mathrm{RH}$. A spectrum of buffer solution was recorded and subtracted from the spectra of DNA and carboplatin-DNA complexes [23].

\section{4. $C D$ spectroscopy}

CD spectra of pure DNA and its complexes with carboplatin were recorded with an Applied Photophysics chirascan CD spectrophotometer. All spectra were recorded in far UV range $(200-320 \mathrm{~nm})$. Quartz cuvette with a path length of $1 \mathrm{~mm}$ was used for sampling. Three scans were recorded with a scan speed of $1 \mathrm{~nm} / \mathrm{s}$ and averaged. Sample temperature was kept constant $\left(25^{\circ} \mathrm{C}\right)$ during all the experiment with the help of peltier temperature controller. A spectrum of buffer solution was recorded and subtracted from the spectra of DNA and carboplatin-DNA complexes.

\section{Results and discussion}

\subsection{FTIR analysis}

Spectral features of carboplatin-DNA complexes are shown in Fig. 2. Ring vibrations of nitrogenous bases $(\mathrm{C}=\mathrm{O}, \mathrm{C}=\mathrm{N}$ stretching),

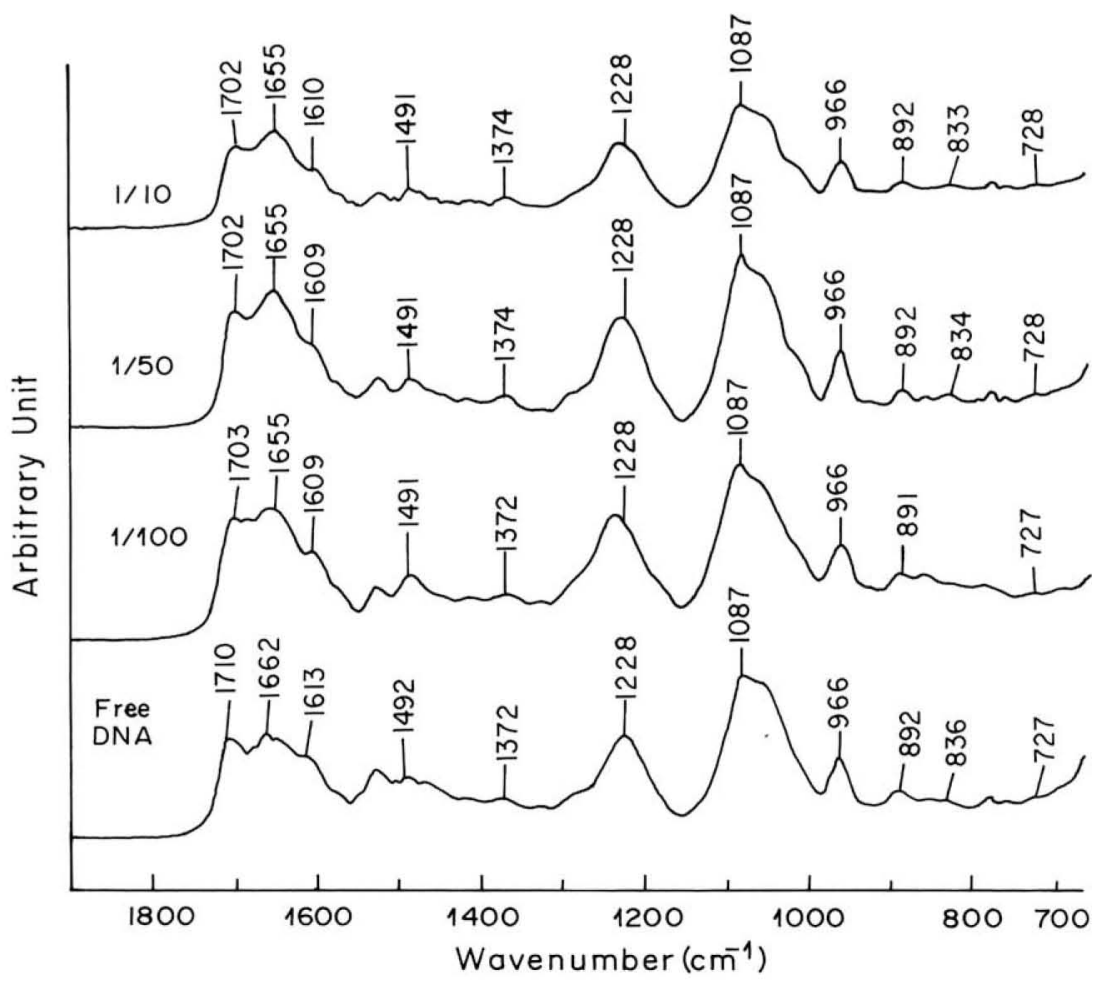




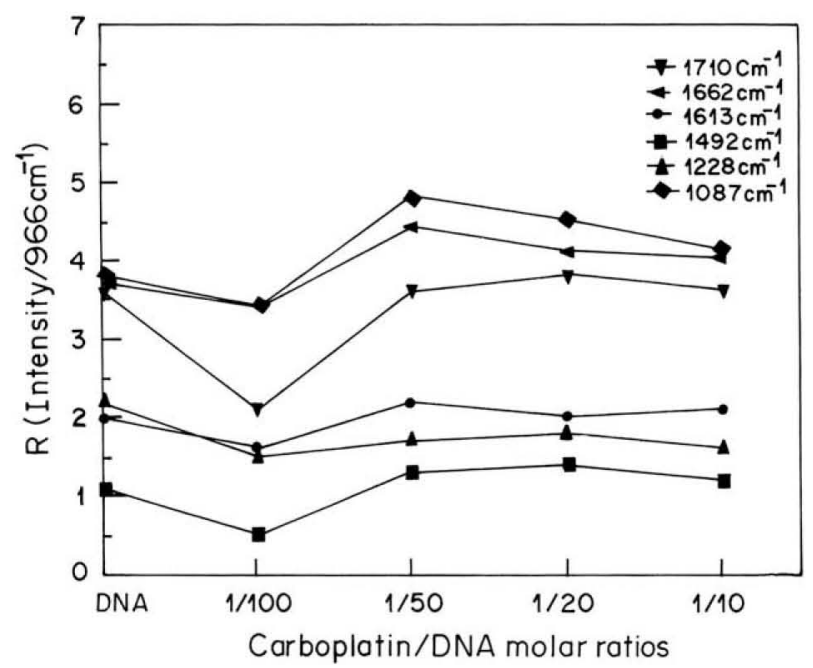

Fig. 3. Intensity ratio variations for DNA as a function of different carboplatin/DNA molar ratios.

$\mathrm{PO}_{2}$ stretching vibrations (symmetric and asymmetric) and deoxyribose stretching of DNA backbone are confined in the spectral region $1800-700 \mathrm{~cm}^{-1}$. Therefore, this particular region is of interest here. The vibrational bands of DNA at 1710, 1662, 1613 and $1492 \mathrm{~cm}^{-1}$ are assigned to guanine $(G)$, thymine $(T)$, adenine $(A)$ and cytosine (C) nitrogenous bases, respectively [24-27]. Bands at 1228 and $1087 \mathrm{~cm}^{-1}$ denote phosphate asymmetric and symmetric vibrations, respectively. These are the prominent bands of pure DNA, which are monitored during carboplatin-DNA interaction at different ratios in this study. Changes in these bands (shifting and intensity) are shown in Fig. 2. After carboplatin addition to DNA solution, guanine band at 1710 shifts to $1702-3$, thymine band at 1662 shifts to 1655 and adenine band at 1613 shifts towards lower wave number $1609-10 \mathrm{~cm}^{-1}$. These shifting can be attributed to direct platin binding to guanine (N7), thymine (O2) and adenine (N7) of DNA bases. No major shifting is observed for phosphate asymmetric and symmetric vibrations.

Fig. 3 shows the intensity ratio variations for DNA vibrations as a function of different carboplatin/DNA molar ratios. Intensity variations of base vibrations related to $\mathrm{G}, \mathrm{T}, \mathrm{A}$ and $\mathrm{C}$ show interesting pattern after the binding of carboplatin with DNA. At low carboplatin/DNA ratio $(r=1 / 100)$, intensity of base vibration decreases, which can be explained by DNA helix stabilization after carboplatin interaction. At $r=1 / 50$, the intensity of base vibrations increases due to helix destabilization. The intensity of base and phosphate vibrations decreases at higher drug concentrations $(r=1 / 20$ and $r=1 / 10)$. This decline in intensity of vibrations is related to DNA aggregation and condensation at high carboplatin concentrations [28]. Phosphate stretching (both asymmetric and symmetric) shows only intensity variations (increase or decrease). Major shifting in wavenumber was not observed for these vibrations, suggesting minor interaction of carboplatin with phosphate group of DNA backbone [26,29].

The sugar band at $1053 \mathrm{~cm}^{-1}$ appears as shoulder in the spectrum of pure DNA. Intensity of band at $836 \mathrm{~cm}^{-1}$ appears slightly week and at the same time $937 \mathrm{~cm}^{-1}$ band cannot be seen in pure DNA spectrum (Fig. 2). This shows a possibility that pure DNA used in the experiment is slightly denatured.

\section{2. $C D$ analysis}

CD spectra of calf-thymus DNA with varying concentrations of carboplatin is shown in Fig. 4. There are four major bands in the spectra for pure DNA, $213 \mathrm{~nm}$ (negative), $223 \mathrm{~nm}$ (positive), $247 \mathrm{~nm}$ (negative) and $277 \mathrm{~nm}$ (positive). These are marker CD bands of double helical DNA in B-conformation [30,31]. When B-to-A DNA transition occurs, CD band at $213 \mathrm{~nm}$ becomes less intense, band at $223 \mathrm{~nm}$ shifts toward higher wavelength, and band at $277 \mathrm{~nm}$ becomes more intense [32]. Binding of carboplatin with DNA does not cause any appreciable shifting in these marker CD bands, indicative of no alteration in B-DNA conformation (Fig. 4). This is further confirmed with our infrared spectroscopic results

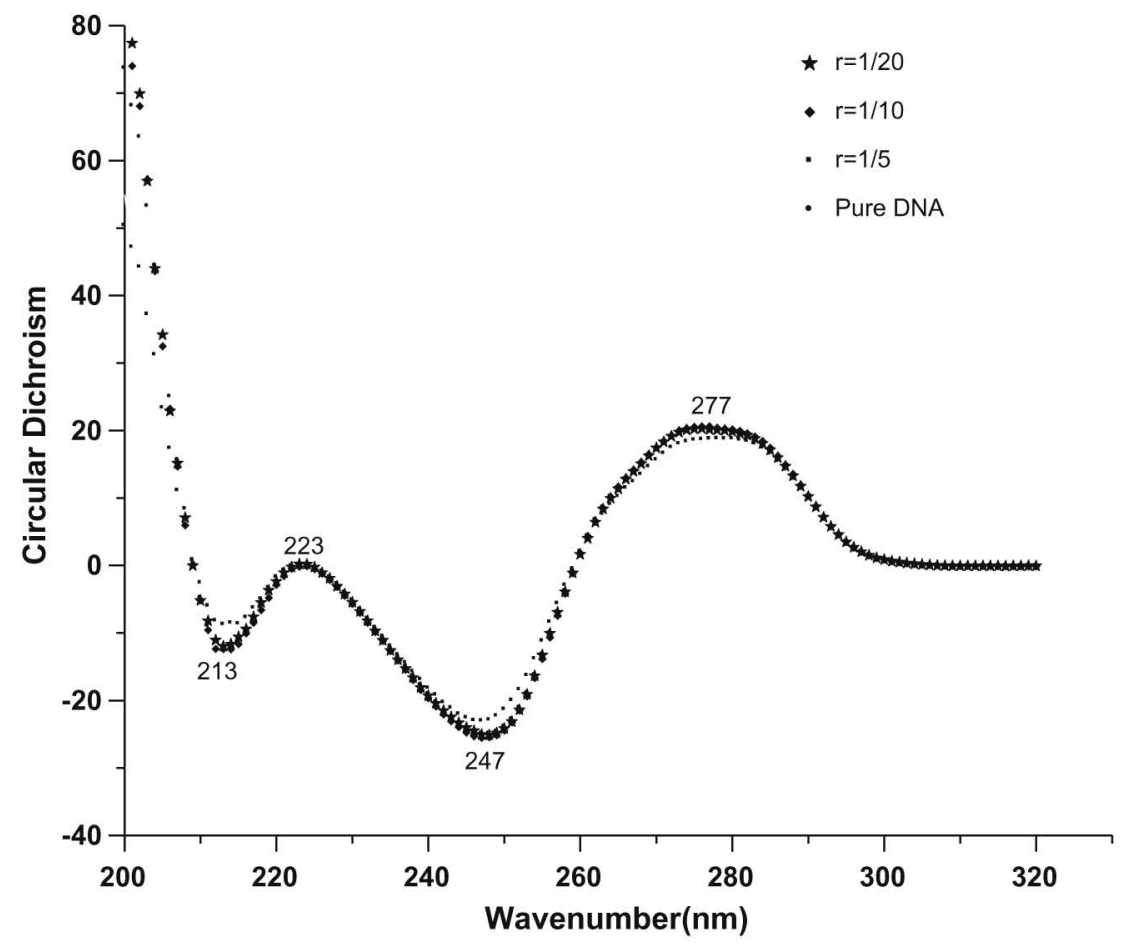


of carboplatin-DNA interactions, which shows no changes for B-DNA marker bands at $1228 \mathrm{~cm}^{-1}\left(\mathrm{PO}_{2}\right)$ and $836 \mathrm{~cm}^{-1}$ (phosphodiester modes). It should be noted that in a B-to- $A$ transition, these B-DNA marker bands shift from 1228 to $1240 \mathrm{~cm}^{-1}\left(\mathrm{PO}_{2}\right)$ and 836 to $810 \mathrm{~cm}^{-1}$ (phosphodiester) $[24,25]$. We did not observe these spectral shifting in IR spectra. In the CD spectra, reduction in the intensity of band at $277 \mathrm{~nm}$ is observed for high carboplatin concentrations $(r=1 / 20$ and $1 / 10)$. This change may be attributed to DNA aggregation as carboplatin content increases in DNA-drug complexes [33].

\section{Conclusion}

The spectroscopic results presented here for carboplatin-DNA interaction indicate that carboplatin binds with DNA through guanine N7, thymine $\mathrm{O} 2$ and adenine N7, with a little binding preference towards phosphate backbone of DNA helix. CD and FTIR spectroscopic analysis revealed that at all concentrations of the drug used in the experiments, DNA remains in the B family of conformations. At higher drug concentrations $(r=1 / 20$ and 1/10) DNA aggregation was observed.

\section{Acknowledgement}

One of the authors D.K.J. is thankful to Indian Council of Medical Research for financial support as junior research fellow (No. 3/1/ JRF/8/MPD/2007(31849)).

\section{References}

[1] A.J. Waqstaff, A. Ward, P. Benfield, R.C. Hell, Drugs 37 (2) (1989) 162.

[2] E.R. Jamieson, S.J. Lippard, Chem. Rev. 99 (1999) 2467.

[3] P. Jordana, M. Carmo-Fonsecab, Cell. Mol. Life Sci. 57 (2000) 1229.

[4] D.Z. Yang, A.H.J. Wang, Prog. Biophys. Mol. Biol. 66 (1997) 81.

[5] S.E. Sherman, S.J. Lippard, Chem. Rev. 87 (1987) 1153.

[6] J.H.J. Den Hartog, C. Altona, G.A. van der Marel, J. Reedijk, Eur. J. Biochem. 147 (1985) 371.
[7] J.H.J. Den Hartog, C. Altona, J.H. van Boom, G.A. van der Marel, C.A.G. Haasnoot, J. Reedijk, J. Biomol. Struct. Dyn. 2 (1985) 1137.

[8] F. Herman, J. Kozelka, V. Stoven, E. Guittet, J.P. Girault, T. Huynh-Dinh, J. Igolen, J.Y. Lallemand, J.C. Chottard, Eur. J. Biochem. 194 (1990) 119.

[9] D.B. Zamble, D. Mu, J.T. Reardon, A. Sancar, S.J. Lippard, Biochemistry 35 (1996) 10004.

[10] J.C. Huang, D.B. Zamble, J.T. Reardon, S.J. Lippard, A. Sancar, Proc. Natl. Acad. Sci. USA 91 (1994) 10394.

[11] O. Fleck, C. Kunz, C. Rudolph, J. Kohli, J. Biol. Chem. 273 (1998) 30398.

[12] G. Chu, J. Biol. Chem. 269 (1994) 787.

[13] M.J. Allday, G.J. Inman, D.H. Crawford, P.J. Farrell, EMBO J. 14 (1995) 4994.

[14] E. Froehlich, A. Gupta, J. Provencher-Mandeville, E. Asselin, J. Bariyanga, G. Bérubé, H.A. Tajmir-Riahi, DNA Cell Biol. 28 (1) (2009) 31.

[15] R. Marty, A.A. Ouameur, J.F. Neault, S. Nafisi, H.A. Tajmir-Riahi, DNA Cell Biol. 23 (3) (2004) 135.

[16] S. Nafisi, A. Sobhanmanesh, K. Alimoghaddam, A. Ghavamzadeh, H.A. TajmirRiahi, DNA Cell Biol. 24 (10) (2005) 634.

[17] C.N. N'soukpoé-Kossi, C. Descôteaux, E. Asselin, J. Bariyanga, H.A. Tajmir-Riahi, G. Bérubé, DNA Cell Biol. 27 (6) (2008) 337.

[18] S.A. Lee, B. Sclavi, J.W. Powell, W. Williamson III, A. Rupprechat, Phys. Rev. E 48 (1993) 2240.

[19] Y.Z. Chen, A. Szabo, D.F. Schroter, J.W. Powell, S.A. Lee, E.W. Prohofsky, Phys. Rev. E 55 (1997) 7414.

[20] W. Zhenxin, Z. Zheling, D. Shaojun, Spectrochimica Acta Part A 59 (5) (2003) 949.

[21] G. Siligardi, R. Hussain, Enantiomer 3 (2) (1998) 77.

[22] R. Vijayalakshmi, M. Kanthimathi, V. Subramanian, U.N. Balachandran, Biochem. Biophys. Res. Commun. 271 (2000) 731.

[23] S. Alex, P. Dupuis, Inorg. Chim. Acta 157 (1989) 271.

[24] E. Taillandier, J. Liquier, Methods Enzymol. 211 (1992) 307.

[25] D.M. Loprete, K.A. Hartman, Biochemistry 32 (1993) 4077.

[26] A. Ahmed Ouameur, H.A. Tajmir-Riahi, J. Biol. Chem. 279 (2004) 42041.

[27] V.V. Andrushchenko, Z. Leonenko, H. van de Sande, H. Wieser, Biopolymers 61 (2002) 243.

[28] A. Ahmed Ouameur, H. Arakawa, H.A. Tajmir-Riahi, Biochem. Cell Biol. 84 (2006) 677.

[29] N. Chistopher, N'soukpoé-Kossi, C. Descô teaux, E. Asselin, H.A. Tajmir-Riahi, G. Bérubé, DNA Cell Biol. 27 (2008) 101.

[30] M. Vorlickova, Biophys. J. 69 (1995) 2033.

[31] K. Nejedly, J. Chladkova, M. Vorlickova, I. Hrabcova, J. Kypr, Nucl. Acids Res. 33 (2005) 1.

[32] J. Kypr, M. Vorlickova, Biopolymers 67 (2002) 275.

[33] C.N. N'soukpoé-Kossi, A. Ahmed Ouameur, T. Thomas, A. Shirahata, T.J. Thomas, H.A. Tajmir Riahi, Biomacromolecules 9 (2008) 2712. 